\section{EREM 76/4}

Journal of Environmental Research, Engineering and Management

Vol. 76 / No. 4 / 2020

pp. 32-45

DOI 10.5755/j01.erem.76.4.27448
Eco-design Methods and Tools: An Overview and Applicability to Packaging

\begin{tabular}{|l|l}
\hline Received 2020/08 & Accepted after revision 2020/10 \\
\hline
\end{tabular}

\title{
Eco-design Methods and Tools: An Overview and Applicability to Packaging
}

\section{Visvaldas Varžinskas, Zita Markevičiūtè}

Kaunas University of Technology, Centre for Packaging Innovations and Research, Studentų str. 54, Kaunas, Lithuania.

\section{leva Kazulytè, Valda Grigolaitè, Valdonė Daugèlaitė}

Kaunas University of Technology, Institute of Environmental Engineering, Gedimino str. 50, Kaunas, Lithuania.

*Corresponding author: erem@ktu.lt

Eco-design is used as a tool in the product and service sectors with the aim to increase sustainability and reduce negative environmental impact on the product design stage. When analyzing available information on eco-design methodologies from the point of view of applicability to the packaging, it often becomes unclear which method should be preferred and would best suit the specific application.

This paper explains the main principles of eco-design and sustainable application advantages and aims to show the benefits of applying eco-design strategies and methodologies into the development of sustainable packaging. The highlighted differences between the design methods, available tools and their features helps with finding the most suitable specific sustainable packaging design application.

Keywords: packaging, eco-design, environmental impact, eco-design methodologies, eco-design tools.

\section{Introduction}

Nowadays, the packaging sector generates a growing waste stream, which accounts for between 15\% and 20\% of total municipal solid waste in different countries (OECD,
2011, p. 131). The packaging waste market share is very significant and has a big potential to grow making a direct negative impact on human health and environment. 
According to Grönman et al. (2012), the main task of packaging is to protect and distribute the right product to the right end-user in a safe, cost-efficient and user-friendly way. Thus, the principal roles of packaging are to protect the product from outside influences and damage and keep it safe in the supply chain (Lee and Lye, 2003, Coles 2003; González-García et al., 2016). Williams and Wikström (2011) point to the role of packaging in reducing food waste and minimizing the environmental impact from the whole food packaging system.

Packaging must be designed so that it has minimal or no negative environmental effect and makes no damage to human health. The use of the eco-design concept, which takes into consideration the environmental impacts of materials, resources and end-of-life scenarios at the front end of a design project, enables making choices that reduce the impact of the product on the environment and can be helpful first of all in achieving the goals related to environmental efficiency.

The aim of this study is to analyze the eco-design approach and the related methods used in the development of eco-friendly products in general and the applicability of the eco-design approach to packaging products taking into account numerous diverse requirements, the aggregate of which makes the packaging segment different compared with other product groups. This article comprises the following: an overview of the eco-design concept, the packaging role and eco-design aspects which apply to the packaging design, the specific requirements from the point of view of environmental impact; analysis of the eco-design approach and an overview of design methods thereof as well as challenges related to possible applications of eco-design tools in practice; classification of eco-design tools and methods for industrial product designers and a brief overview of European Union legal requirements that packaging manufacturers must comply with.

\section{Eco-design. Importance and impact}

During the product development process, a product's function, its operating principles, shape and material are determined and with that the most prevailing technical, economical as well as ecological product properties are specified (Kattwinkel and Bender, 2020). The product's function means adopting the product according to the consumer needs using technical and technological innovations. Ergonomic implications mean that the designed product has to be comfortable to use, easy to pack, transport, install and maintain. Ergonomics is also described as an innovation and safety factor within the design process that ensures that the specific nature of the "human factor" is fully integrated into the design approach (Sagot et al., 2003). Technological implications cover engineering and industrialization aspects, as well as the aesthetic appearance - shapes, materials and surfaces, colors, and graphics. Ecological implications involve the materials used, the energy consumed, product and process environmental impact, recycling or disposal of the whole product or its parts at the end of product life. An eco-design technique consists of applying environmental criteria to product development (GonzálezGarcía et al., 2016). The main principle of eco-design is very simple - use less and do more, i.e., the efficiency in using materials for production, efficiency of production process, the way product operates in its use phase and how it is managed at the end of its life. Eco-design key steps involve selection of low impact materials and reduction of material usage in the production process; product techniques and distribution process optimizations; reduction of product environmental impact while using it; new concept development, i.e., how product can be re-designed at the end of its life; optimization of initial lifetime and end of life considering ways of how the materials can be recovered or re-used.

Rising concerns over industrial damage to climate change and environmental degradation, i.e., pollution of water, air and soil as well as lack of resources, encourage environmental performances and eco-design integration into business operations. In order to achieve the most efficient results, eco-design should be applied in a very early stage of product and packaging development. Eco-design takes into the full environmental impact of a product from the very beginning of its life cycle; thus, eco-design is of particular importance in the whole concept of the circular economy (European Commission, 2009).

In the past decades, the sustainable product policy has also been on a focus of global and European Commission agenda. Recently, European sustainable product policies such as Eco-design of Energy-Related Products (ErP), European Union Ecolabel, Green Public Procurement and Energy Label, have been supplemented by the latest initiative - European Green Deal plan - which 
indicates climate and environmental related challenges and emphasizes the importance of modern, resource-efficient processes implementation. One of the pre-requisites in order to minimize the impact on the environment and climate change is waste recovery and reduction policy. New requirements to ensure that all packaging in the EU market are reusable or recyclable in an economically viable will be mannered by 2030 (European Green Deal plan, 2020).

\section{Eco-design packaging}

Packaging is defined as any material which is used to contain, protect, handle, deliver or present goods (European
Commision). Sustainable packaging combines product protection with the environmental impact, consumption and disposal (Cass et al., 2011). The sustainability of packaging includes the conditions that result from the importance of eco-design, manufacturing, choice of materials, product type, consumption and ultimate environmental protection (Platcheck et al., 2008).

In general, packaging must meet a variety of requirements, such as legislative, functional, and safety; it also has to follow innovative design trends, i.e., those of unique attractive design and simple usage. The summarized main eco-design concept aspects at the packaging and system levels are listed in Table 1.

Table 1. Main Aspects of Packaging Eco-design (Ecodesign-packaging, 2018).

\begin{tabular}{l|l}
\multicolumn{1}{c}{ At the system level } & \multicolumn{1}{c}{ At the packaging level } \\
\hline Deposit-supported, return systems for reusable packaging & Product protection \\
\hline Deposit-supported, return systems for single use packaging & Minimizing pollutants \\
\hline Improved sorting and recycling systems & Residual emptying \\
\hline Resource-efficient logistics (e.g., avoidance of transport, cooling) & Needs-based packaging size \\
\hline Waste prevention along the supply chain (goods and packaging) & Optimizing packaging weight and volume \\
\hline & Use of recycled material \\
\hline & Use of bio-based materials \\
\hline & Capability of being ascertained, sorted and recycled
\end{tabular}

\section{Choice of materials}

Materials play a significant role in eco-design packaging. The global packaging market has to meet diverse needs of multiple industries and sectors. The main packaging materials are glass, paper and cardboard, plastics, metals and wood. Less popular packaging materials are textile and ceramics. Different packaging has a different sorting and terminology. Packaging made of a single material, such as glass, plastic, metal or paper, is called simple packaging. Packaging made of different materials that are indistinguishable is called combined packaging or mixed-materials (combination of plastic, paper, and metal, usually layered or fused together, e.g., a coffee spoon where the packaging is made by melting plastic and metal foil, or packaging of milk or juice made by reinforcing paper, plastic and foil). Composite packaging consists of different materials that can be separated by hand from each other (e.g., a paper candy box covered with a protective plastic wrap) (Packaging Organization, 2018). Looking from the eco-design perspective, combined or mixed-materials packaging in most of the cases does not meet sustainability requirements as this kind of packaging is difficult to recycle and usually it does not biodegrade at all or /and without making a negative environmental impact.

Consumers may significantly share the responsibility for the reduction of the packaging environmental footprint by sorting packaging for recycling or participating in composting programs. But the main impact and innovative solutions have to be started and implemented in the packaging industry. The selection of the most suitable materials for packaging design and their recycling 
potential is a key environmental concern. Nowadays, a big priority is given to packaging made from renewable resources and with a sustainable product end of life (recyclable or biodegradable) that has less or no negative impact to the environment.

Figure 1 indicates the characteristics of plastics. Plastic usage is a major concern of the European Commission as the plastic packaging share of all the total packaging takes up to 40\% (Nieroa and Hauschilda, 2017; EC, 2018) and raises controversial debates on environmental impacts. Conventional plastic products, although

Fig. 1. Plastics family.

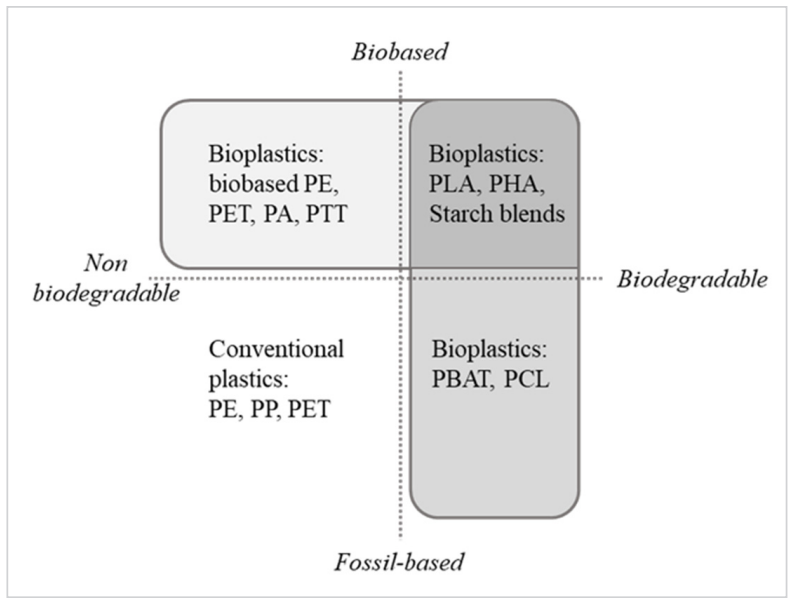

Source: European Bioplastics association. very useful, create a huge damage to the environment, by polluting water resources and the entire ecosystem. Accumulation of conventional plastic in the environment, reduction of arable land, wear oil wells, releasing gases during incineration have prompted efforts to develop biodegradable packaging/plastics (Mohatny et al., 2015). Another group of plastics is bioplastics. Bioplastics can be fossil-based or bio-based (from renewable resources), can be biodegradable and non-biodegradable. Biomaterials (biopolymers) are polymers produced from renewable sources. Biopolymers are made from renewable resources - animal materials or plant materials. Their main feature is biodegradability. Biopolymers can be classified based on chemical structure, origin, methods of synthesis, cost-effectiveness, applications, etc. (Davidovic and Savic, 2010).

The selection of raw material is one of the main aspects that has to be evaluated in packaging design and production. The amount of raw materials (less is more) is another important indicator in eco-design. The environmental impact of packaging can be measured by the weight of the materials used in the packaging developed (Anne Emblem, 2012). To assess the environmental impact of packaging, the composition of the products used should be considered when designing the packaging (Heller, 2017). Product design must achieve the highest environmental benefit with minimal packaging resources (Fig. 2).

Fig. 2. Simplified packaging eco-design scheme.

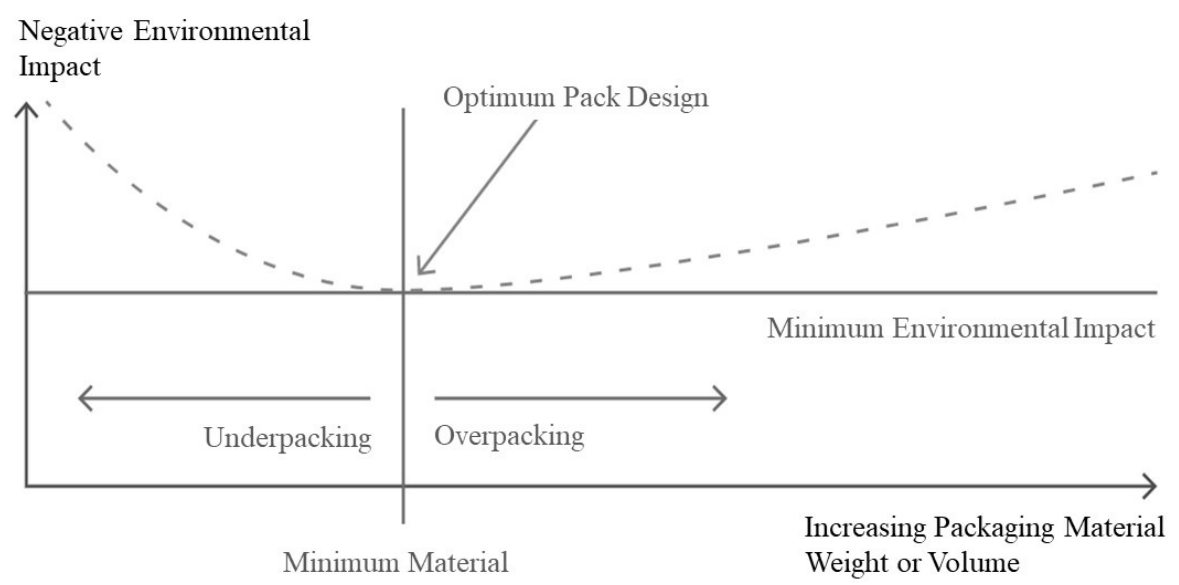

Source: ECR Europe 
The third important aspect is frequency of usage and reusability or a re-design option. Disposable packaging is intended for single use and then discarded, such as disposable cups, take away food containers, ready meal disposable bowls, while reusable packaging can be used more than once, such as plastic bottles that are washable and refillable (Processing organization, 2018). Disposable or single use packaging in the eco-design concept at the end of the product life should be recycled or biodegraded/composted. Re-usable packaging at the end of its life should be applicable for reuse or re-design and used again. Packaging optimization based on the eco-design concept is becoming an important marketing factor and conveys the benefits of optimized packaging to the customer. Optimized packaging design can perpetrate products more durable or easier to renew or recycle. This can help recyclers recover their products, recovering valuable materials and components. This saves resources on packaging development (EU Commission, 2015).

There are main four stages of eco-design (Cavalluci et al., 2011):

1 product improvement: gradual product evaluation, such as changing the model using less materials;

2 product redesign: a new product optimized for an existing product;

3 definition of a new product: evaluation of the new product:

4 definition of a new production model.

According to the data, optimal packaging design reduces the environmental impact of the product and also reduces the cost of production (Ribeiro et al., 2008). To achieve these goals, eco-design is driven by external and internal factors (Hemel and Cramer, 2002) (Table 2).

Table 2. The Key Drivers for Eco-design Application Packaging (Hemel and Cramer, 2002; Borchardt et al., 2011; Knight and Jenkins, 2009; Ribeiro et al., 2008).

\begin{tabular}{l|l}
\multicolumn{1}{c|}{ External drivers } & \multicolumn{1}{c}{ Internal drivers } \\
\hline Legislation and government regulations & Environmental product benchmarking \\
\hline $\begin{array}{l}\text { Environmental pressure from industrial organizations } \\
\text { onvironmental demands of customers at the consumer, industrial } \\
\text { or institutional market }\end{array}$ & Commitment to reduce the environmental impact \\
\hline $\begin{array}{l}\text { Negative media attention caused by environmental action groups } \\
\text { components related to the specific option }\end{array}$ & Competitive advantage - image improvement \\
\hline $\begin{array}{l}\text { Competitors have already applied the specific eco-design option to } \\
\text { their products }\end{array}$ & $\begin{array}{l}\text { New market opportunities (competitive advantage: } \\
\text { increasing actual market share/access to new markets }\end{array}$ \\
\hline & $\begin{array}{l}\text { Increase of the product's functional quality } \\
\text { Synergy with product requirements other than functional } \\
\text { quality demands or low costs }\end{array}$ \\
\hline
\end{tabular}

To design and adopt packaging to the industry, consumer and product needs, mathematical simulations, functionally alternative materials assessment tools, eco-design techniques and methodologies can be applied and help to evaluate materials and processes environmental impacts.

\section{Eco-design implementation. Strategies and methodologies}

The product design stage plays a key role in a product life cycle. Depending on a product category or type, up to
$80 \%$ of a product cost could be set at the design stage. Sustainable product design or eco-design is not only a cost saving tool. Often the changes made as a result of employing eco-design strategies and techniques can not only reduce the cost, but help to meet legal obligations, increase product efficiencies and bring a significant impact in reducing the negative environmental effects through the product's life cycle: manufacturing, transportation, consumption, disposal/waste management. The primary focus of eco-design is the environmental impact. Other benefits include an increase in competitiveness 
through cost reduction, entrance into new markets and the launch of new products (Borchardt et al., 2011). According to González-García et al. (2016), Knight and Jenkins (2008), Baker (2016), Pigosso et al. (2010, 2012), Moultrie et al. (2016) and others, eco-design is broadly described as environmental impact assessment. Therefore, there are plenty of tools to perform eco-design ( $T a$ ble 3). As we consider packaging as a product, almost all of the eco-design tools can be applied for packaging eco-design as well.

Different authors submit different eco-design tool categories for packaging. For example, Navajas et al. (2017) determined two main categories: environmental assessment (comprising quantitative ones and qualitative ones) and improvement categories. Navajas et al. (2017) provide an eco-design methodology flowchart (Fig. 3) for reducing the environmental impact of an industrial

Fig. 3. Eco-design methodology flowchart.

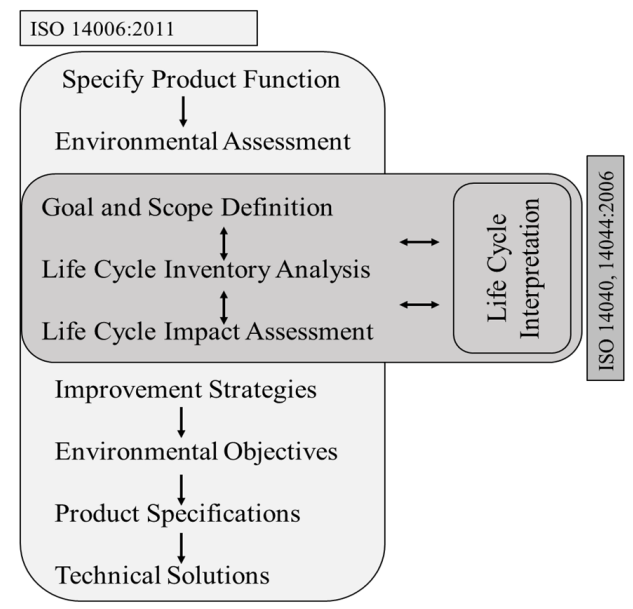

Source: Navajas et al., 2017.

product, described in standard ISO 14006:2011. In this eco-design process methodology, the life cycle assessment (LCA) process, standardized by (1) principles and framework for LCA ISO 14040:2006 and (2) environmental management LCA requirements and guidelines ISO 14044:2006, is included. The methodology consists of the following six steps:

1 product functions identification stage;

2 evaluation of environmental impact;
3 strategies improvement stage;

4 evaluation of environmental objectives stage;

5 product specification stage;

6 technical solutions stage.

The specific product category (e.g. food and beverage, household, electronics) must be identified and evaluated in the packaging design stage. For the complete evaluation process of packaging environmental impacts using Navajas eco-design methodology, recommendations stated in Standard CR 12340:1996 Packaging - Recommendations for conducting life cycle inventory analysis of packaging systems could be included. It is also crucial to choose the right methodology and to comply with national packaging design requirements in order to estimate the environmental impact associated with all stages of product or packaging use.

Knight and Jenkins (2009) chose three categories: guidelines, checklists and environmental tools. Charter and Tischner (2001) proposed four categories: analysis (assessment), prioritization of improvement, aid for creativity, and aid for decision-making, whereas Baumann et al. (2002) classified eco-design tools in six categories: frameworks, checklists and guidelines, rating and ranking tools, environmental tools, software and expert systems and organizing tools.

It is very important to mention inputs and outputs to clarify important issues and make comparisons between options. According to Yan et al. (2001-2002), life cycle assessment (LCA) is a useful tool in analyzing the environmental impact of a product by calculating the inputs and outputs of each stage of a product's life cycle. LCA is used in eco-design as the tool and methodologies for environmental impact quantification (Navajas et al., 2017; Rossi et al., 2016). However, LCA data are usually too complex and detailed to make sense to most business decision makers (Yan et al., 2001-2002).

Basic tools for eco-design are checklists. Checklists give advice on where to focus and what to do; they help to start thinking about certain environmental aspects and not to forget a significant one. Repeated checks can also be a guideline for improvements. Checklists, metrics and indicators offer various criteria for packaging designers. These lists are often very broad, and a packaging designer must have further knowledge on 
Table 3. Eco-design Methodologies and Tools for Packaging Development

\begin{tabular}{|c|c|c|}
\hline $\begin{array}{l}\text { Tools and meth- } \\
\text { odologies for } \\
\text { eco-design }\end{array}$ & Software & Key features \\
\hline \multirow{6}{*}{$\begin{array}{l}\text { LCA for } \\
\text { packaging }\end{array}$} & \multicolumn{2}{|c|}{$\begin{array}{l}\text { It assesses systematically every aspect and environmental impact. It considers the entire product's life since } \\
\text { obtaining of raw material until its end of life. The UNE-EN ISO } 14040 \text { and } 14044 \text { establish the methodology and } \\
\text { requirements for this implementation. }\end{array}$} \\
\hline & PackageSmart & $\begin{array}{l}\text { Allows analyzing packaging options early in the process. For Packaging Designers, it } \\
\text { allows easy comparison of design as well as material decisions during the conception } \\
\text { phase when the cost of change is still low. }\end{array}$ \\
\hline & EarthSmart & $\begin{array}{l}\text { It is a flexible, web-based tool for life cycle assessment }(\mathrm{LCA}) \text {, evaluating the environmental } \\
\text { impacts into the design process of a product or service across its entire life cycle, from } \\
\text { raw materials to disposal and recycling. }\end{array}$ \\
\hline & EIO-LCA Calculator & $\begin{array}{l}\text { Helps rise above the complexity with insights into value chain hotspots and readily } \\
\text { available footprint information to develop winning bids. This system provides a framework } \\
\text { to manage and optimize bidding and tendering processes for contractors and suppliers. }\end{array}$ \\
\hline & $\begin{array}{c}\text { PIQET (Packaging } \\
\text { Impact Quick Evaluation } \\
\text { Tool) from the } \\
\text { Sustainable Packaging } \\
\text { Alliance }\end{array}$ & $\begin{array}{l}\text { It is a streamlined LCA tool designed to assess the environmental impacts and resource } \\
\text { consumption profiles of different packaging options. Identifies and reviews actions to } \\
\text { reduce the environmental impact of packaging system formats, particularly at the } \\
\text { design development stage. }\end{array}$ \\
\hline & $\begin{array}{l}\text { Eco-design } \\
\text { of packaging } \\
\text { pack4ecodesign }\end{array}$ & $\begin{array}{l}\text { The tool calculates the environmental impact of packaging (on } \mathrm{CO} 2 \text {, water and energy) for } \\
\text { each phase of its life cycle. You receive tips and advice for each step on how to improve } \\
\text { packaging, and it can measure the impact of the improvements using a simulation. }\end{array}$ \\
\hline \multirow{3}{*}{ General LCA } & $\mathrm{GaBi}$ & $\begin{array}{l}\text { The web-based configuration tool allows creating life cycle assessments and simulating } \\
\text { alternative packaging designs. }\end{array}$ \\
\hline & OpenLCA & $\begin{array}{l}\text { Very detailed insights into calculation and analysis results; identify main drivers } \\
\text { throughout the life cycle, by process, flow or impact category, visualize results. }\end{array}$ \\
\hline & SimaPro & $\begin{array}{l}\text { Helps effectively apply LCA expertise, to help empower solid decision-making, change } \\
\text { products' life cycles for the better, and improve the company's positive impact. }\end{array}$ \\
\hline \multirow{2}{*}{$\begin{array}{l}\text { MET matrix } \\
\text { (Materials, } \\
\text { energy, toxics) }\end{array}$} & \multicolumn{2}{|c|}{$\begin{array}{l}\text { It is a qualitative tool that allows identifying which elements have environmental significance. It splits the product } \\
\text { in } 3 \text { blocks: materials, energy and toxics, which have to be analyzed in every stage of the life cycle. }\end{array}$} \\
\hline & Maturity Grid & $\begin{array}{l}\text { The Maturity Grid helps designers consider key design trade-offs across the product } \\
\text { life cycle. }\end{array}$ \\
\hline \multirow{4}{*}{ Carbon footprint } & \multicolumn{2}{|c|}{$\begin{array}{l}\text { These simplified methodologies measure the greenhouse gas emission directly or indirectly by a product, } \\
\text { organization, event or individual, splitting them in three blocks. }\end{array}$} \\
\hline & $\begin{array}{l}\text { Environmental } \\
\text { calculator }\end{array}$ & $\begin{array}{l}\text { Allows comparing different materials in terms of carbon usage and calculate } \\
\text { environmental carbon savings. }\end{array}$ \\
\hline & Fefco & $\begin{array}{l}\text { Calculation of a carbon footprint for corrugated packaging. It ensures that members } \\
\text { are permanently informed about the developments that may have an impact on the } \\
\text { corrugated-packaging industry. }\end{array}$ \\
\hline & ArtiosCAD Cape Pack & $\begin{array}{l}\text { ArtiosCAD, Esko's structural design editor and Cape Pack palletizing software work } \\
\text { together seamlessly to help you improve profitability by optimizing packaging design } \\
\text { for shipping. By evaluating the size of your packaging and optimizing the pallet and } \\
\text { truck load, companies are able to make an impressive dent in their carbon footprint. } \\
\text { ArtiosCAD is the ideal product for all corrugated, folding carton and POP, POS, FSDU } \\
\text { display designers. }\end{array}$ \\
\hline
\end{tabular}




\begin{tabular}{|c|c|c|}
\hline $\begin{array}{l}\text { Tools and meth- } \\
\text { odologies for } \\
\text { eco-design }\end{array}$ & Software & Key features \\
\hline \multirow{2}{*}{ Eco-compass } & \multicolumn{2}{|c|}{$\begin{array}{l}\text { The eco-compass is a tool that allows comparing between different product or process options depending on } \\
\text { different design categories. This tool is based in a graphical way of representation, which resembles a spider } \\
\text { web, where each radius is assigned to an assessment criterion. }\end{array}$} \\
\hline & $\begin{array}{l}\text { COMPASS (Comparative } \\
\text { Packaging Assessment) }\end{array}$ & $\begin{array}{l}\text { It is a streamlined life cycle assessment (LCA) tool for rapid packaging design } \\
\text { optimization using industry data. }\end{array}$ \\
\hline \multirow{4}{*}{$\begin{array}{l}\text { Eco-indicator } \\
\quad \text { table }\end{array}$} & \multicolumn{2}{|c|}{$\begin{array}{l}\text { It is a qualitative tool which is easy to use and allows the environmental impact assessment of a product in a } \\
\text { simplified way from impact tables. }\end{array}$} \\
\hline & $\begin{array}{l}\text { The KEPI (Key } \\
\text { Environmental } \\
\text { Performance Indicator) } \\
\text { method }\end{array}$ & $\begin{array}{l}\text { The method is based on the results of a life cycle analysis in order to propose a series } \\
\text { of indicators based on the most significant aspects of a product on the environment. }\end{array}$ \\
\hline & $\begin{array}{l}\text { Product Disassembly } \\
\text { Grid }\end{array}$ & This product evaluation helps improve product design and identify weaknesses. \\
\hline & Eco-indicator 99 & A damage-oriented method for life cycle impact assessment for designers. \\
\hline \multirow{2}{*}{$\begin{array}{l}\text { Eco-design } \\
\text { checklist }\end{array}$} & $\begin{array}{l}\text { The EcoDesign } \\
\text { Checklist }\end{array}$ & $\begin{array}{l}\text { The EcoDesign Checklist is best applied in the concept generation phase, when a clear } \\
\text { idea of a product has been developed. }\end{array}$ \\
\hline & EnviroWise & A pack guide to packaging eco-design. \\
\hline
\end{tabular}

environmental impacts and sustainability in order to be able to choose the most significant and suitable sustainability criteria for the type of packaging in questions (Grönman et al., 2012).

The eco-compass technique is described as a comparative tool to evaluate one existing product with another, or to compare a current product with new development options. It has six dimensions intended to encompass all significant environmental issues (Yan et al., 2001-2002): health and environmental potential risk; resource conservation; energy intensity; mass intensity; revalorization; and service extension.

The holistic framework basic structure is a combination of all elements which need to be included in the eco-design tools. The framework shows that eco-design is a unique and complex discipline with a distinctive approach to problem solving, learning styles and working practices (Lofthouse, 2006).

These eco-design tools can be applied at the design stage of packaging. The choice of tools usually depends on the size of the company, its needs, the volume of material resources and other aspects. It is very important to understand that a proper selection of methodology has a great impact on further effects of packaging to environment.

\section{User-specific comparison of eco-design methodologies and tools}

In order to improve the environmental performance of the packaging product, what needs to be done first is to clearly understand the goals of the development process, to select the right tools for their achievement and not to be lost among a variety of available methods and software. Many packaging designers and engineers do not possess this knowledge, which creates a major barrier to implementing the eco-design approach in this specific industry sector. Investigation of the manner in which the eco-design approach for packaging is typically implemented in today's manufacturing organizations shows that most personnel feel overwhelmed and quick to dismiss it as being unnecessary. Such a condition can be partially explained by an inappropriate or irrational choice of the method to be used. To help with this task, a classification chart of eco-design methods applicable to packaging was developed (Table 4). The chart is composed so that it reflects the specific needs of specialists performing different tasks related to development of environment-friendly packaging.

Table 4 gives the main guidelines to methodologies and tools which are divided into three main groups: for 
Table 4. A User-specific Classification of Eco-design Methodologies and Tools Applicable to Packaging

\begin{tabular}{|c|c|c|c|c|}
\hline For everyone & \multicolumn{3}{|c|}{ For designers, engineers, materials engineers } & \multirow{2}{*}{$\begin{array}{l}\text { For managers } \\
\text { Establish targets at the information } \\
\text { systems to support them }\end{array}$} \\
\hline $\begin{array}{l}\text { Consider environmental } \\
\text { performance early in the } \\
\text { design process }\end{array}$ & $\begin{array}{l}\text { Imprecise data } \\
\text { can guide good } \\
\text { decisions }\end{array}$ & $\begin{array}{l}\text { Consider the } \\
\text { entire product } \\
\text { system }\end{array}$ & $\begin{array}{l}\text { Materials and process } \\
\text { decisions are critical to } \\
\text { environmental impact } \\
\text { and eco design }\end{array}$ & \\
\hline 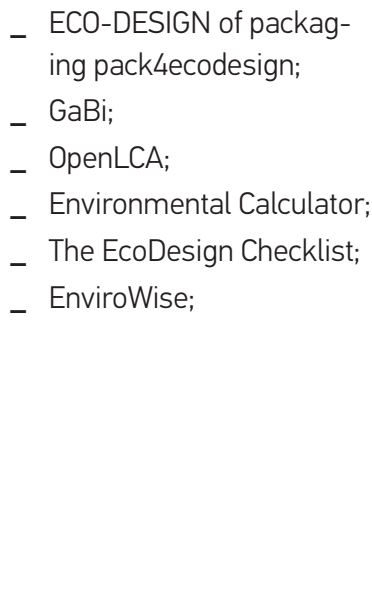 & \multicolumn{3}{|c|}{$\begin{array}{l}\text { - PackageSmart; } \\
\text { _ Earth Smart; } \\
\text { - PIQET (Packaging Impact Quick Evaluation Tool) from } \\
\text { the Sustainable Packaging Alliance; } \\
\text { _ GaBi; } \\
\text { - OpenLCA; } \\
\text { - Maturity Grid; } \\
\text { - } \text { ArtiosCAD Cape Pack; } \\
\text { - Product Disassembly Grid; } \\
\text { - Eco-indicator 99; } \\
\text { - The EcoDesign Checklist; } \\
\text { - EnviroWise; }\end{array}$} & $\begin{array}{l}\text { - ElO-LCA Calculator; } \\
\text { - GaBi; } \\
\text { - OpenLCA; } \\
\text { - SimaPro; } \\
\text { - Environmental Calculator; } \\
\text { - Fefco; } \\
\text { - COMPASS (Comparative Pack- } \\
\text { aging Assessment); } \\
\text { - The KEPI (Key Environmental } \\
\text { Performance Indicator) method; } \\
\text { - Eco-indicator 99; } \\
\text { - The EcoDesign Checklist; } \\
\text { - EnviroWise; }\end{array}$ \\
\hline
\end{tabular}

everyone, for designers, engineers and materials engineers, and for managers. This summarizes the tools of the packaging design process and a selection of appropriate measures. With suitable methodologies and tools in place, the industry can not only improve with delivering the eco-design packaging, but can easily identify methodologies and tools according to needs.

\section{Legal requirements for packaging}

Waste prevention, and in particular the prevention of packaging waste, is one of the key issues for Europe. Packaging manufacturers must comply with the Packaging (Essential Requirements) Regulations if they produce packaged goods; design, specify or produce packaging; pack or fill packaging to sell; claim to have packed or filled packaging by putting their brand or trademark on the packaging; or import packaging or filled packaging. The European Commission has approved the EU's Circular Economy Package (CEP, 2018), which sets up the ambitious, legally binding goals for recycling and waste management to reduce landfill, in order to close the loop of product life cycles (Circular Economy Package, 2018). As a part of the circular economy package, the European Commission presented an action plan as well as a number of legislative proposals in 2015; and proposals on Waste Framework Directive and Packaging and Packaging Waste Directive were among them (EC, 2015; European Parliament, 2016). In 2018, amendments to both directives were adopted: $2018 / 851$ made amendments to the Waste Framework Directive (2008/98/EC), and 2018/852 made amendments to Packaging and Packaging Waste Directive (94/62/EC). Both directives pay attention to prevention, reuse, and collection of waste streams, and set a number of new recovery and recycling targets.

To implement CEP targets, EU Member States must comply with legal requirements and apply them in their own countries. It depends on each packaging by its own characteristics and it is regulated by some key legal documents, which are reviewed below. The packaging is considered to comply with Directive 94/62/EC if it meets all six harmonized standards.

The related harmonized standards EN 13427-13432 partly filled in the gap and clarified many aspects related to the implementation of the Directive at both the company and the country-wide levels ((EN 13427:2004; EN 13428:2004; EN 13429:2004; EN 13430:2004; EN 13431:2004; EN 13432:2000; Varžinskas et al., 2016) (Table 5)). 
Table 5. Harmonized Standards that Indicate Packaging Compliance to Directive 94/62/EC. Source: European Commission.

\begin{tabular}{|c|c|c|}
\hline Production and composition & Reuse & Recovery \\
\hline $\begin{array}{l}\text { EN 13427:2004 } \\
\text { Requirements for the use of European } \\
\text { Standards in the field of packaging and } \\
\text { packaging waste }\end{array}$ & $\begin{array}{c}\text { EN 13429:2004 } \\
\text { Packaging - Reuse }\end{array}$ & $\begin{array}{l}\text { EN 13430:2004 } \\
\text { Requirements for packaging recoverable by material } \\
\text { recycling }\end{array}$ \\
\hline \multirow[t]{2}{*}{$\begin{array}{l}\text { EN 13428:2004 } \\
\text { Packaging - Requirements specific } \\
\text { to manufacturing and composition - } \\
\text { Prevention by source reduction }\end{array}$} & & $\begin{array}{l}\text { EN 13431:2004 } \\
\text { Requirements for packaging recoverable in the form } \\
\text { of energy recovery, including specification of minimum } \\
\text { inferior calorific value }\end{array}$ \\
\hline & & $\begin{array}{l}\text { EN 13432: } 2000 \\
\text { Requirements for packaging recoverable through } \\
\text { composting and biodegradation - Test scheme and } \\
\text { evaluation criteria for the final acceptance of packaging }\end{array}$ \\
\hline
\end{tabular}

The most important Directive for Eco-design is 2009/125/ EC. The requirements of this directive are applied to energy-use products only (refers to any goods that have an impact on energy consumption during use, when placed on the market and/or put into service). This directive concerns the environment and how to reduce the use of power. The eco-design directive could be expanded in order to include wider environmental aspects especially as regards the packaging.

Even more, there are some standards for eco-design. ISO 14001 links management of an organization's processes with environmental impacts, but does not include design management processes. ISO 9001 covers the design management process, but does not explicitly cover environmental impacts. ISO/TR 14062 and IEC 62430 assist incorporation of the evaluation of environmental aspects and impacts into the design and development process, but as such they do not fully explain the activities involved within an environmental and business management framework, such as those described in ISO 14001.

The regulations aim to minimize the amount of waste produced by packaging and ensure that packaging is either reused, recovered or recycled. It is important that these requirements are taken into account from the very beginning of the design stage. If obeyed and followed in the good packaging design, they can help minimize the amount of packaging needed for goods while still providing sufficient protection. And sometimes a small change in the product design can significantly reduce the amount of packaging it requires and reduce environmental contamination in the future.

The performed analysis has highlighted a number of features that distinguish packaging as a specific product presenting a serious environmental threat: an outstanding diversity of types and a huge volume and variety of materials used for its production, which turn into a waste stream immediately after their life time; packaging development is subject to numerous regulations and requirements related to its functionality (product protection, manufacture, filling, handling and logistics, consumer's health and safety, information, marketing and other aspects) and, finally, its environmental compatibility. Packaging manufacturers must cope with these requirements focusing first of all on those that satisfy the needs of packaging users, including economic attractiveness and price. Fulfilling these requirements requires involvement of significant resources on the packaging manufacturers' side; therefore, environmental issues are often not set as the first priority in companies producing packaging. Lack of skills and knowledge related to the methods and tools used for development of eco-friendly products is yet another reason for such a situation. Many eco-design methods that have been developed for other manufacturing industry or service segments do not necessarily cover all the packaging-specific requirements and, therefore, are not always helpful in case of packaging. 


\section{Conclusions}

Eco-design applications to the packaging industry seem to be a promising way to reduce a negative environmental impact of a product from the very beginning of its life cycle and give the green light in the whole concept of the circular economy. Eco-design is not only a cost saving tool, but it helps to meet legal obligations, increase product efficiencies and bring a significant impact in reducing negative environmental effects through the product's life cycle: manufacturing, transportation, consumption, and disposal/waste management.

The performed analysis highlighted a number of specific features, which distinguish packaging as a product having a huge inevitable environmental impact and being extremely challenging from the point of view of environmental compatibility. These features are the following: enormous diversity of types; a huge volume and variety of materials used for production, which turn into a stream of waste immediately after the life-time of packaging; numerous regulations and requirements related to functionality (product protection, manufacture, filling, handling and logistics, consumer's health and safety, information, marketing and other aspects), market efficiency (competitive price and functionality) and environmental compatibility (compliance with directives, regulations, standards, codes of good practice, guides, etc.).

It is challenging for packaging manufacturers to cope with all the requirements at once, so a rational choice is at first to focus on market-sensitive requirements,

\section{References}

Anne Emblem, 2012. Packaging Technology: Fundamentals, Materials and Processes. https://doi.org/10.1533/9780857095701

Ali, F., Books, C., Bey, N., Design for Sustainability and Project Management Literature - A Review. Procedia CIPR. Vol. 48 / 2016, p. 28-33. https://doi.org/10.1016/j.procir.2016.04.185

Australian Sustainable Packaging Alliance. Available from: http://www.sustainablepack.org.

Baker J., The Environmental Impact of Packaging Design. 2016. Available from: https://www.outerspace.co/outerspace_ news/the-environmental-impact-of-packaging-design/. trying to satisfy the needs of packaging users, like functionality, economic attractiveness and price. Fulfilling the full set of requirements requires involvement of significant resources, which is often difficult to afford for packaging manufacturers. This results in the fact that environmental aspects are often considered not the first priority issue. Furthermore, companies often lack resources, skills and knowledge for selection of the most appropriate methods and tools for development of eco-friendly products. Many eco-design methods that have been developed for other manufacturing industry or service segments do not necessarily cover all the packaging-specific requirements and, therefore, are not always helpful in case of packaging.

As a result of the performed general overview of eco-design methodologies, a systematic list of the methods applicable to packaging was made and their key features were highlighted. The list includes a number of qualitative and quantitative assessment tools, which enable assessment of the environmental impact of packaging through both precise calculations as well as in a simplified way.

To help the company personnel to choose an appropriate eco-design tool, a special classification chart was developed, which evaluates the methods from the user point of view. An employee of the company may select an appropriate method/tool depending on his/her duties in the company and the specific task he/she is set to perform (production planner, design engineer, materials engineer, manager, etc.).

Baumann, H., Boons, F., Bragd, A., Mapping the green product development field: engineering, policy and business perspectives. Journal of Cleaner Production. Vol. 10 / No. 5 / 2002, pp. 409-425. https://doi.org/10.1016/S0959-6526(02)00015-X

Borchardt, M.,Wendt M.H., Pereira,G. M., Sellitto, M. A., 2011. Redesign of a component based on ecodesign practices: environmental impact and cost reduction achievements. Journal of Cleaner Production. Volume 19, Issue 1, January 2011, Pages 49-57. https://doi.org/10.1016/j.jclepro.2010.08.006

Cass, K., Flynn, P., Hong, A., and Rosseter, M., 2011. Designing a Sustainable Packaging Program. Results and Recommendations. 
Cavalluci, D., Guio, R., Cascini, G., 2011. Building Innovation Pipelines through Computer-Aided Innovation- 4th IFIP WG 5.4 Working Conference, CAI 2011. Strasbourg, France, June/ July, 2011. Proceeding. https://doi.org/10.1007/978-3-64222182-8

Charter, M., Tischer, U., Sustainable solution. Journal of Sustainable Product Design. 2001. 2: 151-154.

Coles R., 2003. Introduction. In: Coles R,McDowell D, Kirwan MJ, editors. Food packaging technology. London, U.K.: Blackwell Publishing, CRC Press. p 1-31.

Davidovic' A and Savic' A. (2010): Microbial production of bio degradable polymer. Tehnologica Acta, 3: 3-13 (in Croatian).

DEH - Department of the Environment and Heritage, Canberra, 2001. Product innovation, The green advantage. An introduction to design for environment for Australian business. Available from: https://www.greenbiz.com/sites/default/ files/document/016F20301.pdf.

Department of Business Innovation \& Skills, 2015. Packaging (Essential requirements) regulations. Government guidance notes. Available from: https://assets.publishing.service.gov. uk/government/uploads/system/uploads/attachment_ data/file/460891/BIS-15-460-packaging-essential-requirements-regulations-gov-guidance-notes.pdf.

DS Smiths. Available from: http://www.dssmith.com/packaging/offering/products/packaging/retail-and-shelf-readypackaging/.

EcoDESforFOOD+, 2015. Module 1: Techniques and Methodologies for assessing environmental impact. E-learning Platform.

European Bioplastics association, What are bioplastics? Available online: https://www.european-bioplastics.org/bioplastics/.

European Commission, 2015. Closing the loop - An EU action plan for the Circular Economy. Communication from the Commission to the European Parliament, the Council, the European Economic and Social Committee and the Committee of the Regions $\operatorname{COM(2015)~} 614$ final; 2015. Available from: https://eur-lex.europa.eu/legal-content/EN/TXT/?uri=CELEX\%3A52015DC0614.

European Commission, Food Safety. Available from: https:// ec.europa.eu/food/safety/chemical_safety/food_contact_ materials/legislation_en.

European Commission. Energy efficient products. Available from: https://ec.europa.eu/energy/en/topics/energy-efficiency/energy-efficient-products.

European Commission, The European Green Deal COM/2019/640 final. Available online: https://eur-lex.europa. eu/legal-content/EN/TXT/ ?qid=1588580774040\&uri=CELEX:52019DC0640.
European Committee for Standardization. Standard CR 12340:1996 "Packaging. Recommendations for Conducting Life-Cycle Inventory Analysis of Packaging Systems"; European Committee for Standardization: Geneva, Switzerland, 1996.

Flos Plus. Available from: https://www.fostplus.be/en/enterprises/more-sustainable-packaging.

George G., M., U.S. and EU Requirements for Recycled Food Contact Materials. Journal of food safety. 2013. Available from: https://www.foodsafetymagazine.com/magazine-archive1/ octobernovember-2013/us-and-eu-requirements-for-recycled-food-contact-materials/.

Global Packaging Project. "A Global Language for Packaging and Sustainability". Available from: http://www.pca.org.au/ application/files/8414/3768/9931/gppr.pdf.

González-García, S., Sanye-Mengual, E., Llorach-Masana,P., Feijoo, G., Gabarrell, X., Rieradevall, J., and Moreira, M. T., Sustainable Design of Packaging Materials. 2016, Environmental Footprints and Eco-design of Products and Processes. https://doi.org/10.1007/978-981-287-913-4_2

Grönman, K., Soukka, R., Järvi-Kääriäinen, T., Katajajuuri, J-M., Kuisma, M., Koivupuro, H-K., Ollila, M., Pitkänen, M., Miettinen, O., Silvenius, F., Thun, R., Wessman, H., Linnanen, L., 2012. Framework for Sustainable Food Packaging Design. https://doi.org/10.1002/pts.1971

Guirong,Z., Dehua, L., Zhiping, W., Chenglin, M., 2010. Research on Green Packaging of Circular Economy. https://doi. org/10.1109/ICOIP.2010.238

Heller, M., Packaging and Wasted Food. A report by: Center for Sustainable Systems, University of Michigan. 2017.

Hemel, V., and Cramer, J., 2002. Barriers and stimuli for ecodesign in SMEs. Journal of Cleaner Production, Volume 10, Issue 5, October 2002, Pages 439-453. https://doi.org/10.1016/ S0959-6526(02)00013-6

Horbach, J., Rammer, C., Rennings, K. Determinants of eco-innovations by type of environmental impact - The role of regulatory push/pull, technology push and market pull. Ecological Economics. Volume 78, June 2012, Pages 112-122. https://doi.org/10.1016/j.ecolecon.2012.04.005

Holdway, R., Walker, D., Hilton, M., 2002. Eco-design and successful packaging.

Yan P., Zhou M., Sebastian D., and Caudill R., 2001-2002. Integrating Eco-Compass Concept into integrated product and process development.

James, K., Fitzpatrick, L., Lewis, H., and Sonneveld, K. (2005) Sustainable Packaging System Development. In Leal Filho, W. (ed) Handbook of Sustainability Research. Peter Lang Scientific Publishing, Frankfurt. 
Kattwinkel D., Bender B., Competences for development of ecodesign products, (June 2020), DOI: 10.1017/dsd.2020.43. Available from: https://www.cambridge.org/core/journals/ proceedings-of-the-design-society-design-conference/article/competences-for-the-development-of-ecodesign-products/504C861D35AA0B9BCBA187920F8DA0D3

Knight P., Jenkins J.0, 2009. Adopting and applying eco-design techniques: a practitioner perspective. Journal of Cleaner Production, Volume 17 / No. 5 / 2008, pp. 549-558.https://doi. org/10.1016/j.jclepro.2008.10.002

Lee SG, Lye SW., 2003. Design for manual packaging. International Journal of Physical Distribution and Logistic Management; 33(2): 163-189. https://doi.org/10.1108/09600030310469162

Lofthouse, V., Site Internet Information/Inspiration Pour Aider Les Designers a S'Engager Dans L'Eco-design, Journal of Design Plus Magazine, 2006. p.26.

Maier, A., M., Moultrie, J., Clarkson, P.J. 2011. Assessing organisational capabilities: reviewing and guiding the development of maturity grids. IEEE Transactions on Engineering Management (Volume: 59, Issue: 1, Feb. 2012). https://doi. org/10.1109/TEM.2010.2077289

Mohatny AK, Misra M, Drzal LT, Selke SE,Harte BR, Hinrichsen $G$ (2005): Natural fibers, biopolymers, and biocomposites: an introduction, in Mohatny AK. Natural Fibers, Biopolymers and Biocomposites, CRC Press, Chapter 1. https://doi. org/10.1201/9780203508206.ch1

Moultrie, J., Sutcliffe, L., Maier, A., A maturity grid assessment tool for environmentally conscious design in the medical device industry. Journal of Cleaner Production. Volume 122, 20 May 2016, Pages 252-265. https://doi.org/10.1016/j.jclepro.2015.10.108

Navajas, A., Uriarte, L., Gandia, L., M., Application of Eco-Design and Life Cycle Assessment Standards for Environmental Impact Reduction of an Industrial Product. Journal of Sustainability. 2017 / No. 9. https://doi.org/10.3390/su9101724

Navarro, G., Rizo, C. T., Ceca, B., Ruiz, C., Eco design function and form. Classification of eco design tools according their functional aspects. International conference of engineering design material (2005).

Niero, M., Hauschild, M., Z., Hoffmeyer, S., B., Olsen S. I., 2017. Combining Eco-Efficiency and Eco-Effectiveness for Continuous Loop Beverage Packaging Systems: Lessons from the Carlsberg Circular Community. https://doi.org/10.1111/jiec.12554

Nieroa, M., and Hauschilda, M. Z., 2017. Closing the Loop for Packaging: Finding a Framework to Operationalize Circular Economy Strategies. https://doi.org/10.1016/j.procir.2016.11.209
Pack4ecodesign. Available from: http://www.pack4ecodesign.org/index_en.html.

Pakuociu tvarkymo organizacija. D.C.A., Zanette, E.T., Filho, A.G., Ometto, A. R., Rozenfeld, H., Ecodesign methods focused on remanufacturing. Journal of Cleaner Production, No 18 2010, pp. 21-31. https://doi.org/10.1016/j.jclepro.2009.09.005 Pigosso, D.C.A. and Rozenfeld, H., 2012. Ecodesign Maturity Model: the Ecodesign Practices, Design for Innovative Value towards a Sustainable Society. Springer, USA (2012), pp. 424429. https://doi.org/10.1007/978-94-007-3010-6_81

Platcheck E. R., Schaeffer L., Kindlein W., et al. (2008) Methodology of ecodesign for the development of more sustainable electro-electronic equipments. Journal of Cleaner Production. Vol. 16 (1): 75-86. https://doi.org/10.1016/j.jclepro.2006.10.006

PRAG: Packaging Resources Action Group. An Introduction to Packaging and Recyclability, 2009. Available from: http:// www.wrap.org.uk/sites/files/wrap/Packaging\%20and\%20 Recyclability\%20Nov\%2009\%20PRAG.pdf.

Ribeiro I, Peças P, Silva A et al (2008) Life cycle engineering methodology applied to material selection, a fender case study. Mater Design 16:1887-1899. https://doi.org/10.1016/j. jclepro.2008.01.002

Rao, J., V., S., Thakur, V., Peyyeti, S., Achanta, H. Innovative Trends in Sustainable Packaging.

Rossi, M., Germani, M., Zamagdi, A., Review of ecodesign methods and tools. Barriers and strategies for an effective implementation in industrial companies. Journal of Cleaner Production. 361 - 373. 2016. https://doi.org/10.1016/j.jclepro.2016.04.051

Sagot J.C., Gouin V., Gomes S., Ergonomics in product design: safety factor, Volume 41, Issues 2-3, March 2003, Pages 137154. Available from: https://www.sciencedirect.com/science/ article/pii/S0925753502000383 https://doi.org/10.1016/ S0925-7535(02)00038-3

Sanyé-Mengual, E., García Lozano, R., Farreny, R., Oliver-Solà, J., Gasol, C. M., Rieradevall, J., 2014. Introduction to the eco-design methodology and the role of Product Carbon Footprint.https://doi.org/10.1007/978-981-4560-41-2_1

Saxon Packaging, 2017. Difference between primary, secondary \& tertiary packaging. Available from: http://www. saxonpackaging.co.uk/difference-between-primary-secondary-tertiary-packaging/.

Science for Environmental Policy. DG Environmental News Alert Service. Choosing the best eco-design technique. Availanble from: http://ec.europa.eu/environment/integration/research/newsalert/pdf/142na2_en.pdf. 
Nils de Caluwe, 2004. Business Benefits From Applied EcoDesign. IEEE TRANSACTIONS ON ELECTRONICS PACKAGING MANUFACTURING, VOL. 27, NO. 4, OCTOBER 2004. https:// doi.org/10.1109/TEPM.2004.843144

Subic, A., Paterson, N., 2006. Life Cycle Assessment and Evaluation of Environmental Impact of Sports Equipment. https:// doi.org/10.1007/978-0-387-45951-6_8

Varžinskas, V., Milčius, E., Kazulytè I., Lebedys, A., The Setup of Packaging Development Targeted at Source Reduction and Environmental Regulatory Compliance. Journal of Environmental Research, Engineering and Management, Vol. 72 / No. 2 / 2016 , pp. 71-82.https://doi.org/10.5755/j01.erem.72.2.16101

Verghese, K.,L., Horne, R., Carre, A., 2010. PIQET: the design and development of an online 'streamlined' LCA tool for sustainable packaging design decision support. https://doi. org/10.1007/s11367-010-0193-2

OKALA, Ecodesign Strategy Wheel. Available from: http:// www.okala.net/Okala\%20Ecodesign \%20Strategy $\% 20$ Guide\%202012.pdf.

Zaliasis taskas. Available from: http://www.zaliasistaskas.lt/ pakuociu-rusys.html.
OptimEco.ca. Available from: http://www.optimeco.ca/en/ ecodesign-initiative/lifecycle.

EUROPEN - The European organization for packaging and the environment. Available from: http://www.europen-packaging.eu/ policy/5-eu-packaging-and-packaging-waste-directive.html.

European Commission, 2009. Ecodesign Your Future. How Ecodesign can help the environment by making products smarter.

Corner-i. Ecodesign - ISO 14006: 2011: In-depth. Available from: https://app.croneri.co.uk/topics/ecodesign-iso-14006-2011/ indepth.

Eco3e. Eco-design tools. Available from: http://eco3e.eu/en/ base/indicators/.

European standard. Environmental Management - Life cycle assessment - Principles and framework (ISO 14040:2006).

Ecodesign - packaging, 2018. Available from: https://ecodesign-packaging.org/en.

Williams, H., and Wikström, F. (2011). Environmental impact of packaging and food losses in a life cycle perspective: a comparative analysis of five food items. Journal of Cleaner Production. Volume 19, Issue 1, January 2011, Pages 43-48. https://doi.org/10.1016/j.jclepro.2010.08.008 